\title{
Filozofia e munguar për të shkuarën
}

\author{
Agim Baçi
}

“...Për ata që diktatura i zhvesh nga dinjiteti i tyre për çdo ditë, deri sot, unë do të doja të them, qoftë dhe një fjali të vetme që përmban fjalën "shami". T'i pyes thjesht: KENI NJE SHAMI? Ka mundësi që kjo pyetje, në çdo kohë, të mos ketë asnjë lidhje me shaminë, por me vetminë e mprehtë të qenies njerëzore...”. Këto janë fjalët e shkrimtares Rita Muller gjatë ceremonisë së Nobelit më 2009. Muller, shkrimtare rumune e emigruar në Gjermani, për t'i shpëtuar persekutimeve të sistemit të ish-diktatorit Çaushesku, ka përshkruar në veprën e saj, por edhe në ceremoninë e dhënies së çmimit Nobel më 2009, atë pamundësi për të jetuar në liri apo dinjitet brenda rrethit ku gjithçka fashitej prej dhunës dhe ideologjisë së mbrapshtë komuniste. Ajo i drejtohet "vetmisë së mprehtë", atje ku njeriu i kthen shpinën gjithçkaje që ka të bëjë me njerëzoren, madje edhe vetes.

Por a kemi mundur "t'ia drejtojmë tjetrit këtë shami" tjetrit në këto 28 vite ndryshimesh politike? Fjalët e Rita Mullerit dhe pyetja nëse duhej bërë një hap i tillë me tjetrin është një pyetje që përfshin këdo që guxon të mendojë për një çast lidhur me fytyrën absurde dhe dehumane që mori diktatura e Enver Hoxhës.

Një pyetje të tilla më shumë ma solli ndërmend ngjarja e 29 viteve më parë të hyrjes së qindra shqiptarëve në Ambasada, më 2 korrik 1990, si dhe leximi i librit-dëshmi i Ethem Fezollarit me ngjarjen e largët të vitit 1975, kur 16 pjesëtarë të së njëtës familje, të rritur e fëmijë, vendosën të provonin jetën e lirë ose vdekjen. Me një varkë të prodhuar në mënyrë krejt artizanale, që sot është në muzeun Kriminalistik të Akademisë së Rendit Publik në Shkup, ata sfiduan ferrin për së gjalli, të jetuar për 26 vjet, që nga arratia më 1949 të babait të tyre, partizanit Hekuran Fezollari. Vendosën dhe me fat kaluan liqenin, në të gdhirë të 4 korrikut 1975, ndërkohë që vdekja dhe jeta ndahej 


\section{Albanon}

\section{Revistë kulturore}

nga një fill i hollë. Por Zoti kish vendosur ndryshe për familjen Fezollari.

Ka aty në libër emra pa fund, që kanë jetuar në atë kohë e që janë gjallë edhe sot, si vetë protagonist i librit. Ka emra që ai veçse i risjell me gjithë brutalitetin, skllavërinë mendore, dhunën e mbështetur në urdhërat e partisë. Madje, si për të plotësuar atë fytyrë të dhunës dhe mungesës totale të respektit për njeriun, risillet në skenë therja e lopës së familjes Fezollari nga Këshilli Popullor menjëherë pas arratisjes së 16 familjarëve, me shprehjen "Po therim Kushen!". Kushja ishte nëna e Ethemit, e shoqja e Hekuranit. Efekti i asaj që ndodhte nuk kishte e nuk ka as sot fjalë për një përshkrim.

E sot, edhe pse kanë kaluar shumë vite, sërish vlen të pyesim: a kanë vijuar të jenë rrezik ata që skllavërisht, në emër të pushtetit, në emër të ideologjisë, prodhuan dhe drejtuan dhunën për gjysëm shekulli? Në këto 25 vite nuk mundëm kurrë t’i themi shumë gjëra me zë të lartë. Librat e At Zef Pllumit, Ejll Çobës, Spartak Ngjelës, Lek Pervizit, Visar Zhitit, Uran Butkës, Çelo Hoxhës, Jonila Godoles, apo edhe të shumë të tjerëve që dëshmuan më së paku jetët e tyre, kaluan më shumë si kuriozitet, pa mundur të bëhen pjesë e një debati të madh kombëtar, e aq më pak pjesë e kurrikulave të shkollës shqiptare.

Por përse na duhet ky debat lidhur me të shkuarën në diktaturë? Përse duhej të kishim filozofuar mbi atë çfarë ndodhi me shqiptarët nga vetë shqiptarët në më shumë se 45 vite? Si mund të jetë sot shpirti i atyre që nuk nguruan të përfaqësojnë atë dhunë, por e kundërshtuan atë? Çfarë mund t’i ketë thënë fëmijëve të tij, çfarë edukate mund t’i ketë dhënë ai komandanti që provoi të fuste në dhe të gjallë dhe lakuriq Mitrush Kutelin, sepse ishte shkrimtar që nuk e donte diktatura? (Dëshmi e Hamza Tushës botuar nga gazetarja Admirina Peçi). Si mund të ketë edukuar fëmijët e tyre punonjësit e ish-Sigurimit famëkeq që përdhunonin gruan dhe vajzën 15-vjeçare të inxhinierit Agron Canajt, duke i çuar deri në vetëvrasje, pasi refuzoi të bashkëpunonte për të denoncuar miqtë e tij? Si munden gjithë ata dhunues dhe përdhunues t'u kenë buzëqeshur fëmijëve të tyre, pasi kanë treguar fytyrën më çnjerëzore, me antihumane që mbjell ideologjia komuniste?

Gjithë kjo mungesë e debatit mbi të vërtetën e kohës së diktaturës, edhe pse tashmë e kemi një ligj që i ka dhënë viston njohjes me dosjet, na rikthen drejt disa pyetjeve: A jemi ne të gatshëm të përballemi me pytjet që na përshkruajnë identitetin, karakterin dhe, për më tepër, aftësinë tonë për t'u përballur me të vërtetën? A duhet ta njohin brezat e sotëm njeriun që shkoi deri në honin më të thelllë të shpirtit, që u denatyrua deri në pikën sa 
mund të ndëshkonte fëmijën, gruan, vëllain, motrën, shokun, sepse kështu ia kërkonte partia?

A kemi pyetur ne në këto vite se cilat janë pasojat e përpjekjes së një klase historianësh që tentojnë të bëjnë normale për të pamendueshmen e atyre krimeve qoftë gjatë Luftës, ashtu edhe në diktaturë? A do të duhet vërtet ta mendojmë rutinë atë proces të krimit nga qindra adhurues të ideologjisë së asaj kohe, të cilët justifikohen "ashtu ishte koha"?

Ne në këto vite, jo vetëm që kemi refuzuar të shihemi në pasqyrën e së shkuarës, por edhe jemi në atë rrugë që prof. Hysamedin Ferraj e konsideron si "njeriu hobsian". Sipas Ferrajt, një njeri i tillë moralin, fenë, artin, shkencën, filozofinë, njeriun tjetër, shoqërinë dhe shtetin, nuk i ka natyra të brendshme, por vetëm proteza në rrugën drejt rritjes të fuqisë dhe pushtetit. (“E pafilozofuara”, H. Ferraj, f. 21).

Ne kemi nevojë të dëshmojmë se mund të përballemi me pasqyrën e vetes sonë, me tjetrin, me të të vërtetën e së shkuarës, mbi kuptueshmërinë e qëndrimeve morale. Përndryshe, pyetjen e nobelistes Muller "Keni një shami?" do të na duhet ende shumë kohë ta kuptojmë se përse e kemi tmerrësisht të nevojshme. 